\title{
Moduli of Maximum Runoff in Snow Melt Floods on Rivers of the Southeastern Part of Esil River Basin
}

\author{
P.A. Plekhanov ${ }^{1}$, N.V. Popov ${ }^{1}$, N.N. Medeu ${ }^{2}$, L.N. Nikiforova ${ }^{1}$ \\ ${ }^{1}$ Laboratory of Natural Hazards, «Geography and water safety institute» Joint Stock Company, Kabanbai batyr / Pushkin St. 67/99 -050010, \\ Almaty, Republic of Kazakhstan \\ ${ }^{2}$ Laboratory of Water resources, «Geography and water safety institute» Joint Stock Company, Kabanbai batyr / Pushkin St. 67/99 -050010, \\ Almaty, Republic of Kazakhstan
}

\begin{abstract}
:
The Esil River Basin, including its southeastern part, is subject to frequent floods and inundations. The hydrometeorological knowledge of the basin is insufficient. Therefore, methods for calculating runoff moduli at unexplored river catchments are in demand. The article proposes one of such methods, developed using data of test catchments. Based on the use of the developed method in the dry steppes of Central Kazakhstan, it was found that in small catchments with area of up to $1000 \mathrm{~km}^{2}$, the maximum modulus of snowmelt runoff of 100 year return period is $390,1-450$ and more $1 / \mathrm{s}^{*} \mathrm{~km}^{2}$, and at catchments from 1,000 to $5,000 \mathrm{~km}^{2}-230,1-390 \mathrm{l} / \mathrm{s} * \mathrm{~km}^{2}$, from 5,000 to 10,000 $\mathrm{km}^{2}-170,1-230 \mathrm{l} / \mathrm{s}^{*} \mathrm{~km}^{2}$, from 10,000 to $16,500 \mathrm{~km}^{2}-90-$ $170 \mathrm{l} / \mathrm{s}^{*} \mathrm{~km}^{2}$.
\end{abstract}

Keywords - Floods, Snow Melt Floods, Inundations, Moduli of Maximum Runoff of Snow Melt Floods, Factors of Snowmelt Runoff.

\section{INTRODUCTION}

The Esil River is a transboundary river and belongs to the category of large in area, but small by its river flow. The river originates from the mountains in Central Kazakhstan called Niyaz at an altitude of $800 \mathrm{~m}$. Initially it flows from the southeast to the northwest, then after $680 \mathrm{~km}$ it turns north and then after $810 \mathrm{~km}$ it crosses the border with Russia, where it flows into the Irtysh River. The length of the river in Kazakhstan's territory is about $1780 \mathrm{~km}$, the area of basin is $147,04 \mathrm{~km}^{2}$ [1], and the drop of level from its source to the border with the Russian Federation is $700 \mathrm{~m}$ (from 800 to $75 \mathrm{~m})$.

The Esil River Basin is divided into 6 sites by the water authorities of the republic [1]. The first 2 ones are attributed by the authors to the southeastern part of the basin (Figure 1), which are investigated in this article. The first site is "The source of the river - Nur-Sultan water storage reservoir" with a catchment area of 4,942 thousands $\mathrm{km}^{2}$ and the site number 2 is "Nur-Sultan water storage reservoir - the mouth of the Zhabay River in the city of Atbasar" (a right tributary of the Esil River) with a catchment area of 48,474 thousands $\mathrm{km}^{2}$ [1].

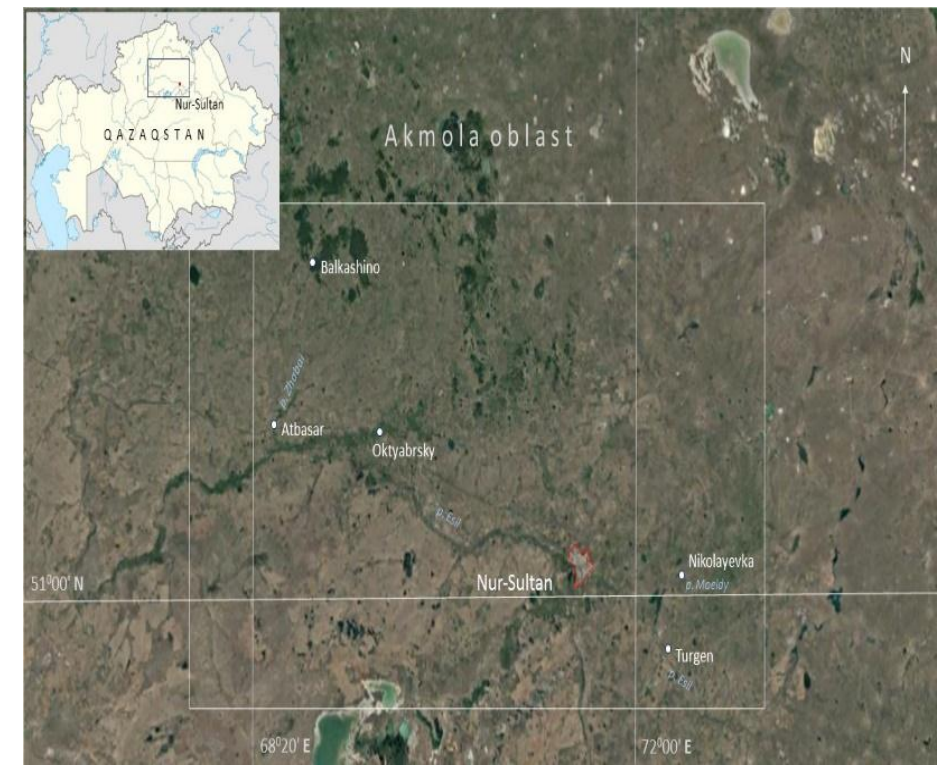

Fig. 1. The region under research of the moduli of maximum runoff in snow melt flood - the southeastern part of the Esil

River Basin. 1 - location of the Nur-Sultan water storage reservoir

The researched area (Fig. 1) is the subject to frequent floods and inundations both on the main riverbed and its tributaries. Since 1975, 22 flush floods have been recorded in this region (1980, 1983, 1985, 1986, 1990, 1993, 1994, 1995, 1996, 2003, 2004, 2005, 2007, 2011, 2014 (3), 2015, 2016 (2), 2017 (2), with the most damage caused by the recent floods observed in 2014-2017.

A dense drainage network is developed in the southeastern part of the Esil River Basin and a flat relief prevails with low mountains along the outskirts of the southeastern part of the basin - up to 600-800 m (Figs. 2, 3). During major floods in the region, numerous flood zones arise, causing significant damage to settlements, agriculture and production. As a rule, terrain inundations occur unexpectedly, intensively and not always in the same areas as before. Unfortunately, floods and inundations in Kazakhstan are not properly studied. 


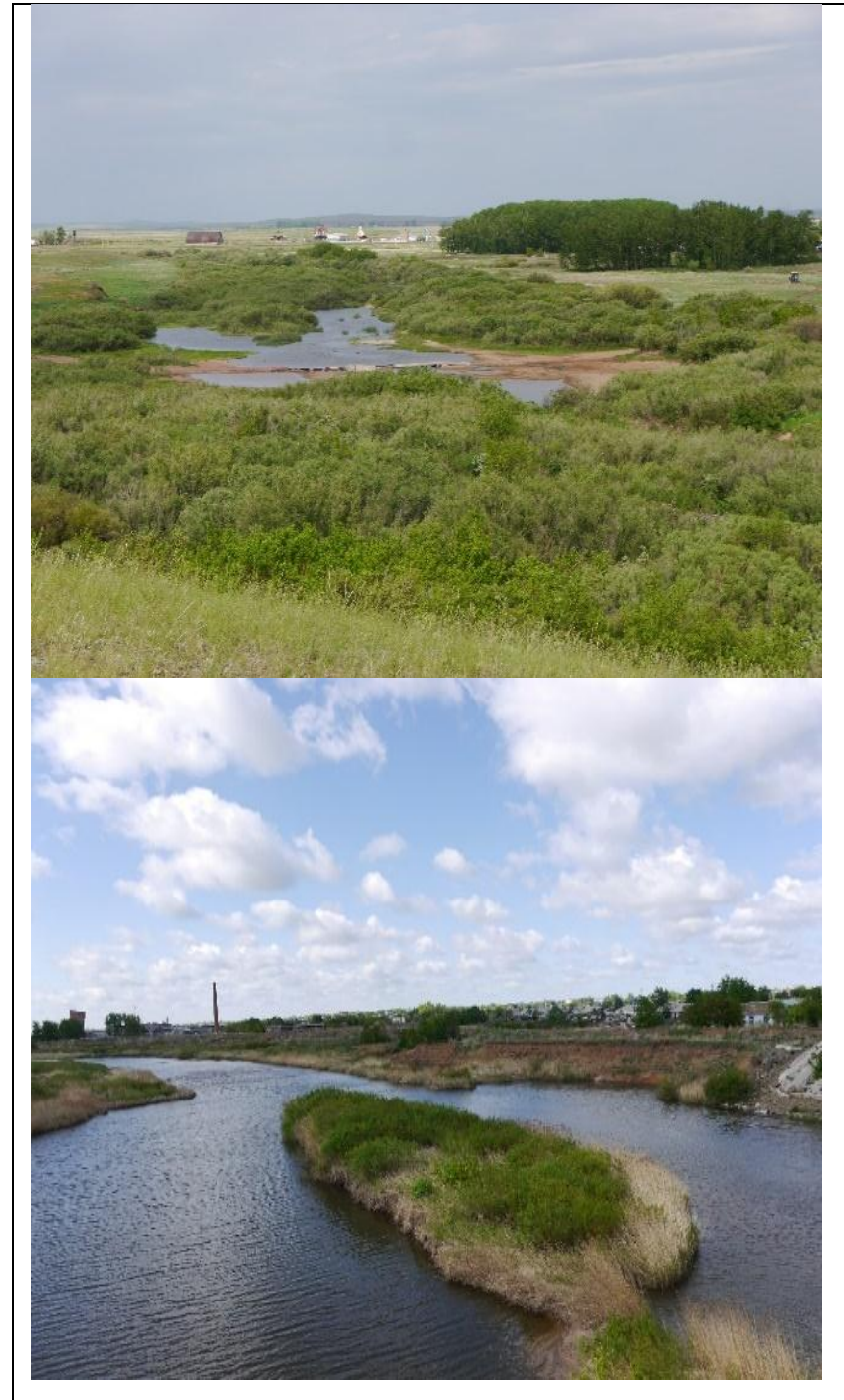

Fig. 2. Typical landscapes in the southeastern part of the Esil River Basin: overhead - the sources of Esil River; below - the Zhabay River near the city of Atbasar, $2 \mathrm{~km}$ from the confluence of the Esil River [2]

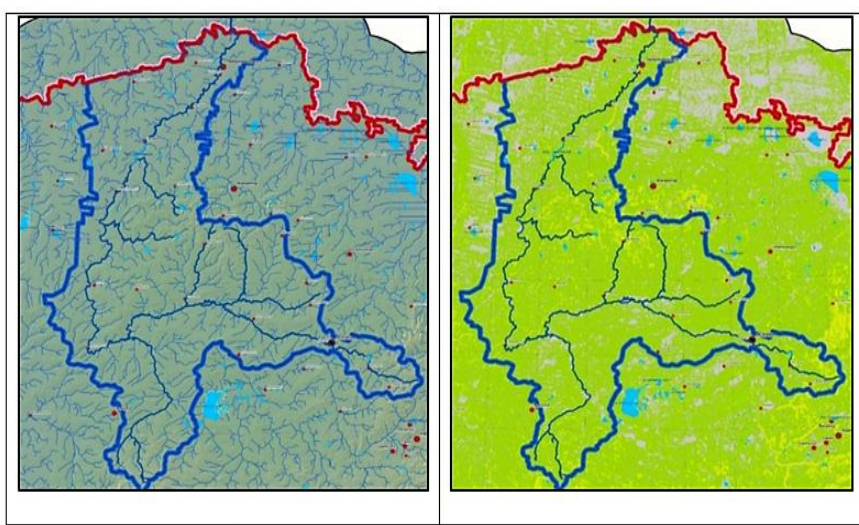

Earth surface's slopes, in degrees ${ }^{\circ}$

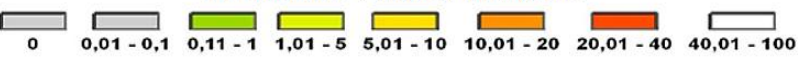

Fig. 3. Physical and geographical conditions of the Esil River Basin: on the left - hydrography; on the right - slopes of the earth's surface [3]
The aim of this work is to develop a method for calculating the moduli of maximum runoff for unexplored catchments in the southeastern part of the Esil River Basin. The number of such catchments is large. It was determined that the Esil River in the site from the source to the mouth of the Zhabay River has only about 25 first-order tributaries with a length of $15 \mathrm{~km}$ or more (Fig. 2, overhead), which pose a real danger during floods.

Similar studies were carried out in the work [4], where local relations of the moduli of the maximum snowmelt runoff from the mean height of the river basins of the Northwest Caucasus were established, which were used to estimate this runoff on the unexplored rivers. It was shown in the work [5] that, for an approximate estimation of the spring runoff norm and the maximum runoff modulus of unexplored rivers in Central Kazakhstan, the relations of the spring runoff layer from the catchment area and the relation of the maximum runoff modulus from the catchment area of the study area can be used.

During the research, geographic, analytical, hydrological, statistical and comparative research methods were used.

\section{RESULTS AND DISCUSSION}

\section{II.I Selection of Test Catchments for Determining Maximum Runoff Moduli}

The southeastern part of the Esil River Basin is located in the dry-steppe zone of the republic. Only in the north part there are places of forest-steppe territories.

The hydrological knowledge of the southeastern part of the Esil River Basin is insufficient. There are currently 7 stream gauges in this region, of which 3 ones are located in the riverbed of the main river, and others in its tributaries.

The basic principle of selecting test catchments for determining the maximum runoff moduli was the presence of undistorted observational data and their representativeness. For this reason, data on the Esil River stream gauges - Volgodonovka village and Nur-Sultan city were rejected due to the regulatory influence of the Nur-Sultan water storage reservoir on the flow in the river stations of these stream gauges.

As a result, the series of maximum discharges for only 5 observation points were selected for analysis. There are $r$. Esil - v. Turgen; r. Moiyldy - v. Nikolaevka; r. Kalkutan - v. Kalkutan, r. Zhabay - c. Atbasar and r. Zhabay - v. Balkashino.

The first stream gauge is located in the upper reaches of the Esil River, and the flow here is almost unregulated, except for the influence of the small Esil water storage reservoir with a volume of about 9,0 million $\mathrm{m}^{3}$. The next 4 stream gauges are located on the tributaries of the main river and also do not have any distortions according to the measured data associated with economic activity. 
International Journal of Engineering Research and Technology. ISSN 0974-3154, Volume 13, Number 6 (2020), pp. 1314-1318

(C) International Research Publication House. https://dx.doi.org/10.37624/IJERT/13.6.2020.1314-1318

Table 1. Stream gauges located in the southeastern part of the Esil River Basin

\begin{tabular}{|c|c|c|c|c|c|c|c|}
\hline \multirow{2}{*}{ № } & \multirow{2}{*}{ River } & \multirow{2}{*}{$\begin{array}{c}\text { The name of the } \\
\text { stream gauge }\end{array}$} & \multicolumn{2}{|c|}{ Validity period } & \multirow{2}{*}{$\begin{array}{c}\text { Distance from } \\
\text { the mouth, } \mathrm{km}\end{array}$} & \multicolumn{2}{|c|}{ Catchment } \\
\cline { 7 - 9 } & & Open & Closed & $\mathrm{km}^{2}$ & $\mathrm{H}_{\text {avg., }} \mathrm{m}$ \\
\hline 1 & Esil & v. Turgen & 15.06 .1974 & Functions & 2367 & 3240 & 524 \\
\hline 2 & Esil & v. Volgodonovka & 19.07 .1977 & Functions & 2299 & 5400 & 450 \\
\hline 3 & Esil & c. Nur-Sultan & 01.09 .1932 & Functions & 2241 & 7400 & 430 \\
\hline 4 & Moiyldy & v. Nikolaevka & 08.07 .1972 & Functions & 22 & 492 & 530 \\
\hline 5 & Kalkutan & v. Kalkutan & $\begin{array}{l}01.01 .1936 / \\
14.04 .1955\end{array}$ & Functions & 44 & 16500 & 361 \\
& & & & & & & \\
\hline 6 & Zhabay & v. Balkashino & 14.10 .1959 & Functions & 144 & 922 & 440 \\
\hline 7 & Zhabay & c. Atbasar & $01.06 .1936 /$ & \multirow{2}{*}{ Functions } & 16 & 8530 & 364 \\
\hline
\end{tabular}

\section{II.II Specifications of Test Catchments}

The Esil River - at the village of Turgen. The catchment is represented by the upper territory of the Esil River. It is located on the hilly terrain covered with meadow vegetation with the altitude range between $450 \mathrm{~m}$ and $800 \mathrm{~m}$ above sea level. The weighted average (WA) catchment altitude is $524 \mathrm{~m}$. The Esil River in this site is formed by the confluence of several streams taking its origins from the Niyaz Mountains. The length of the river along the main riverbed is $71 \mathrm{~km}$, the catchment area is $3240 \mathrm{~km}^{2}$.

The Moiyldy River - at the village Nikolaevka. The river is the right tributary of the Esil River and flows into the water storage reservoir called Nur-Sultan. The catchment is located on a hilly area covered by meadow vegetation in the altitude range of $404-730 \mathrm{~m}$. The weighted average catchment altitude is $530 \mathrm{~m}$ above sea level, the length of the river is about $35 \mathrm{~km}$. The river is formed from the confluence of brooks, that flow at the foot of unnamed mountain hills. The catchment area is $492 \mathrm{~km}^{2}$.

The Kalkutan River - at the village Kalkutan. The Kalkutan River is the largest tributary of the Esil River. Its length is about $170 \mathrm{~km}$, and the basin area is $16,500 \mathrm{~km}^{2}$. The catchment of the river stretches parallel to the Esil's riverbed from east to west. The river forms on hills covered with meadow vegetation at altitudes of $350-550 \mathrm{~m}$. The Kalkutan River has a large tributary called Arshaly, which is $70 \mathrm{~km}$ long, originating in the Kokshetau's upland, partially in the forest-steppe zone (less than $5 \%$ by area). The weighted average catchment altitude is $371 \mathrm{~m}$ above sea level.

The Zhabay River - at the city of Atbasar. The river originates from the uplands of the Kokshetau in the forest-steppe zone at altitudes of $600-700 \mathrm{~m}$. It flows from north to south. It has the length of about $140 \mathrm{~km}$ and the large tributary called Zhilandy with the length of about $70 \mathrm{~km}$. The basin area is $8,500 \mathrm{~km}^{2}$. Weighted average catchment altitude is $364 \mathrm{~m}$.

The Zhabay River - at the village of Balkashino. It is represented by the upper territory of the Zhabay river. The forest cover of the catchment is about $50 \%$, the area is $922 \mathrm{~km}^{2}$, and the weighted average altitude is $440 \mathrm{~m}$ above sea level.

Regarding the test catchments, partially not including the last one, it should be noted that all of these catchments are located in almost uniform physical and geographical conditions - in the dry steppes of Central Kazakhstan. Differences in the average altitudes of catchments are not significant - not more than 200 $\mathrm{m}$, and it is unlikely that these differences will significantly affect the maximum runoff.

\section{II.III The Formation of Runoff of Snowmelt Floods}

The factors that determine the formation of snowmelt runoff can be divided into 2 main groups. These are meteorological factors that determine the intensity of snowmelt and evaporation processes, and factors that define the processes of accumulation and regulation of snowmelt runoff, as well as its losses on the surface of catchments.

The types of accumulation and regulation of snowmelt runoff on the slopes are as follows [6]: 1) accumulation of water in the layer of seasonal snow cover; 2) the accumulation of water on the surface of the catchment; 3) accumulation in soil 4) regulation of runoff by micro brook network.

The next stage in the formation of snowmelt flood runoff is the temporary storage of snowmelt runoff, which is largely determined by the total area of catchment and the nature of the channel network. The larger the catchment and the more complex the channel network, the smaller the resulting runoff moduli. Therefore, to solve practical problems in determining runoff moduli at unexplored catchments, it is desirable to have ones at the slope border - river course. Thereby, in this research, runoff moduli for the initial stages of the channel network were determined along basins of tributaries or small catchments, where the influence factor of catchments' areas is minimal.

Table 2 shows the results of statistical calculations of runoff moduli of $1 \%, 5 \%$ and $10 \%$ of probability for 4 selected basins 
International Journal of Engineering Research and Technology. ISSN 0974-3154, Volume 13, Number 6 (2020), pp. 1314-1318

(C) International Research Publication House. https://dx.doi.org/10.37624/IJERT/13.6.2020.1314-1318

for the same period - 1975-2015, which almost completely

corresponds to the last full water cycle on the Esil River.

Table 2. Maximum water discharges $\left(\mathrm{Q}_{\mathrm{m}}\right)$ and maximum runoff moduli $\left(\mathrm{M}_{\mathrm{m}}\right)$ on the rivers of the southeastern part of the Esil River basin for the period 1975-2015

\begin{tabular}{|c|c|c|c|c|c|c|c|c|}
\hline \multirow[t]{3}{*}{ Name of the river - stream gauge } & \multirow{3}{*}{$\begin{array}{c}\text { Catchment } \\
\text { area, } \\
\left(\mathrm{km}^{2} / \mathrm{H}_{\mathrm{wA}}, \mathrm{m}\right)\end{array}$} & \multirow{3}{*}{$\begin{array}{l}\text { River } \\
\text { length, } \\
\text { km }\end{array}$} & \multicolumn{6}{|c|}{$\begin{array}{c}\text { Maximum water discharges in } \mathrm{m}^{3} / \mathrm{s} \text { and maximum } \\
\text { runoff moduli in } 1 / \mathrm{s}^{*} \mathrm{~km}^{2}\end{array}$} \\
\hline & & & \multicolumn{2}{|c|}{$1,0 \%$} & \multicolumn{2}{|c|}{$5,0 \%$} & \multicolumn{2}{|c|}{$10,0 \%$} \\
\hline & & & $\mathrm{Q}_{\mathrm{m}}$ & $\mathrm{M}_{\mathrm{m}}$ & $\mathrm{Q}_{\mathrm{m}}$ & $\mathrm{M}_{\mathrm{m}}$ & $\mathrm{Q}_{\mathrm{m}}$ & $\mathrm{M}_{\mathrm{m}}$ \\
\hline $\begin{array}{l}\text { Esil River }-\mathrm{v} \text {. Turgen (upper reaches of } \\
\text { the Esil River) }\end{array}$ & $3240 / 524$ & 71 & 724 & 223 & 506 & 156 & 409 & 126 \\
\hline $\begin{array}{l}\text { Moiyldy River - v. Nikolaevka (a } \\
\text { tributary of the Esil River) }\end{array}$ & $472 / 492$ & 35 & 220 & 466 & 137 & 290 & 107 & 227 \\
\hline $\begin{array}{l}\text { Kalkutan River }-\mathrm{v} . \text { Kalkutan (the } \\
\text { tributary of the Esil River) }\end{array}$ & $16500 / 371$ & 175 & 1478 & 90 & 964 & 58 & 743 & 45 \\
\hline $\begin{array}{l}\text { Zhabay River - Atbasar city (the tributary } \\
\text { of the Esil River) }\end{array}$ & $8530 * / 364$ & 140 & 1547 & 181 & 1024 & 120 & 798 & 94 \\
\hline $\begin{array}{l}\text { Zhabay River }-\mathrm{v} . \text { Balkashino (the } \\
\text { tributary of the Esil River) }\end{array}$ & $922 * * / 440$ & 40 & 200 & 217 & 150 & 163 & 127 & 138 \\
\hline
\end{tabular}

Based on the data in Table 2, the relations of the maximum runoff moduli $(\mathrm{Mm})$ of the rivers of the southeastern part of the Esil River Basin from the catchment areas for $1 \%, 5 \%$, and $10 \%$ of probabilities of these moduli were revealed. When identifying these relations, data on the Zhabay River Balkashino stream gauge were not used, since the maximum runoff moduli for this one are significantly lower than the background stream gauges due to the high forest cover of this catchment (about 50\%).

Table 3 presents the averaged coordinates of the revealed relations of the maximum runoff moduli for the rivers of the southeastern part of the Esil River Basin on the catchment areas.

Table 3. Moduli of maximum runoff $\left(1 / \mathrm{s}^{*} \mathrm{~km}^{2}\right)$ for catchments in the southeastern part of the Esil River Basin

\begin{tabular}{|c|l|l|l|l|l|l|l|l|l|}
\hline \multirow{2}{*}{$\begin{array}{c}\text { Runoff modulus } \\
\text { probability }\left(\mathrm{M}_{\mathrm{m}}\right) \text { in } \%\end{array}$} & \multicolumn{8}{|c|}{ Catchment area, thousand $\mathrm{km}^{2}$} \\
\cline { 2 - 12 } & $\leq 0,5$ & 1,0 & 2,0 & 3,0 & 4,0 & 5,0 & 10,0 & 15,0 & $\geq 16,5$ \\
\hline $1 \%$ & $\geq 466$ & 390 & 300 & 260 & 240 & 230 & 170 & 110 & $\leq 90$ \\
\hline $5 \%$ & $\geq 300$ & 270 & 220 & 175 & 140 & 130 & 100 & 60 & $\leq 50$ \\
\hline $10 \%$ & $\geq 220$ & 180 & 140 & 120 & 110 & 100 & 80 & 50 & $\leq 45$ \\
\hline
\end{tabular}

According to the Table 3, we can draw the following conclusions:

1) during extreme snowmelt on the slopes of the catchments in the southeastern part of the Esil River Basin, the maximum runoff of 100 year return period in small catchments can be 466 or more $1 / \mathrm{s} * \mathrm{~km}^{2}$ or in the water layer $40,3 \mathrm{~mm}$ per day. At the same time, on the large catchments with the area of several thousand $\mathrm{km}^{2}$, the maximum runoff modulus is significantly reduced and will be 2-3 times less - up to $100-2001 / \mathrm{s}^{*} \mathrm{~km}^{2}$ (Table 3).
The objectivity of the established scales of the maximum values of snowmelt runoff, for example, is confirmed by the results of hydrological studies on small glaciers of the Ile Alatau (Northern Tien Shan), for which the maximum daily average runoff moduli were determined in the amount of 0,4-0,5 and more $\mathrm{m}^{3} / \mathrm{s} * \mathrm{~km}^{2}[7]$.

2) the danger of small catchments during extremely intense snowmelt increases sharply when there are conditions for the occurrence of unexpected local floods during the frozen state of soils and the formation of water-snow flows with sharp higher air temperature and heavy liquid precipitation on melting snow cover; 
International Journal of Engineering Research and Technology. ISSN 0974-3154, Volume 13, Number 6 (2020), pp. 1314-1318

(C) International Research Publication House. https://dx.doi.org/10.37624/IJERT/13.6.2020.1314-1318

3) the data in Table 3 can be used for a preliminary assessment of the exposure of valuable territories to possible rare inundations and floods.

\section{CONCLUSION}

The significant relation of the maximum snowmelt runoff moduli for the rivers of the southeastern part of the Esil River Basin on the catchment areas was revealed.

The method is proposed for approximate determination of the maximum melt runoff moduli for unexplored small and medium catchments in the southeastern part of the Esil River Basin according to the catchment area information.

It has been established that in the dry steppes of Central Kazakhstan, the maximum snowmelt runoff modulus of 100 year return period in small catchments (up to $500 \mathrm{~km}^{2}$ ) can reach 466 or more $1 / \mathrm{s}^{*} \mathrm{~km}^{2}$.

Small catchments in the southeastern part of the Esil River Basin pose a real danger for the occurrence of local floods during a combination of negative extreme circumstances.

The article was prepared by the «Geography and water safety institute» JSC within the framework of the grant project of the MES RK № AR05135407 «Dangerous Hydrological Phenomena (floods) Control in the Esil basin (Akmola and North Kazakhstan provinces) in Changing Climate».

\section{REFERENCES}

[1] Tverdovsky AI. Integrated use of water resources of the Esil River Basin. - UNDP project "Development of a national plan for IWRM and water conservation in Kazakhstan" component: creation of Basin Councils. Astana, 2007.

[2] Plekhanov PA, Schoenberger IV, Medeu NN. Influence of underlying surface conditions on the formation of inundation and floods in the Esil basin. Questions of geography and geo-ecology. 2018;3:79-93.

[3] Plekhanov PA, Medeu NN. Extreme Hydrological Phenomena in the Esil River Basin: Genesis, General Patterns of Manifestation. Journal of Ecological Engineering. 2019;20(7):187-195.

[4] Melnikova TN. Maximum drain of a spring river high water in the Northwest Caucasus. Peer-reviewed scientific journal "Vestnik ASU". 2014;3(142):158-164.

[5] Pshenchinova AS, Opp C., Jussupbekov DK. Determination of characteristics spring flood flow in the absence of observational data. Bulletin of KazNU. Geographical series. 2019;3(54):42-48.

[6] Sokolovsky DL. River flow. Leningrad: Gidrometeizdat, 1968.

[7] Plekhanov PA, Dzhampeisov TO. The flow regime in the nival-glacial belt of Zailiysky Alatau. Results and prospects of physical and geographical research in Kyrgyzstan. Frunze: Ilim, 1988. 